\title{
ANTINEOPLASTIC DNA-BINDING COMPOUNDS: INTERCALATING AND MINOR GROOVE BINDING DRUGS
}

\author{
Katarina MIŠKOVIĆ ${ }^{1}$, Maro BUJAK ${ }^{2}$, Mirela BAUS LONČAR ${ }^{2}$, and \\ Ljubica GLAVAŠS-OBROVAC ${ }^{1}$
}
J. J. Strossmayer University, Faculty of Medicine, Department of Medicinal Chemistry, Biochemistry and Clinical Chemistry, Osijek ${ }^{1}$, Ruđer Bošković Institute, Department of Molecular Medicine, Laboratory for Systems Biomedicine, Zagreb², Croatia

Received in March 2013

CrossChecked in August 2013

Accepted in September 2013

\begin{abstract}
DNA intercalating and minor groove binding compounds are new weapons in the battle against malignant diseases. These antineoplastic agents target the DNA molecule and interfere with the cell cycle leading to rapidly proliferating cell death. They are mainly derivates of a naturally occurring organic compound derived from a microorganism or plant. Intercalators usually act as topoisomerase I and/or II poisons, while the mechanisms of DNA minor groove binders are a combination of several steps including topoisomerase poisoning. This paper gives an overview of some of the developed DNA intercalating and minor groove binding compounds, as well as an explanation of their chemical structures, origins, and application in chemotherapy.
\end{abstract}

KEY WORDS: chemotherapy, DNA intercalator, DNA minor groove binder, organic compounds derivatives

Cancer or neoplasm is one of the major diseases of modern society, appearing in all age groups. The notion that cancer is a multi-step process involving accrued genetic damage has now been generally wellaccepted (1).Cancer is characterised by rapid, abnormal, and uncontrolled specific cell division with increased rate of DNA synthesis and very fast metabolism that requires a high rate of glycolysis (2).

When it comes to the treatment of cancer, nature was the main source of remedies until the middle of the nineteenth century when aspirin, the first synthetic remedy, was made (3). In the last 70 years, more than 175 antitumour drugs have been produced and commercialised, $65 \%$ of which were derived from natural products $(4,5)$ or were newly-synthesized molecules that contained pharmacophores from natural products (3). Chemicals that alkylate DNA have been used in cancer treatment since 1942 (1). To this day, antineoplastic therapy has been primarily quantitative rather than qualitative because the impact of a therapy is measured through its killing effects and not its specificity. Such therapies are most effective in rapidly dividing tumour cells like lymphomas and leukaemias but also affect normal rapidly dividing cells such as bone marrow cells (6) and various epithelial tissues (7). An ideal anticancer drug should specifically target malignant cancer cells and leave non-malignant cells unaffected (6). Having in mind that the molecular structure of a single tumour type differs between individuals, chemotherapy cannot be considered reliable. Modern antitumour therapeutic 
approaches include case individualisation whenever possible as well as the application of modern techniques such as DNA microarrays in order to achieve this individualisation (8).

Molecular studies are showing promise in the development of more efficient antitumour strategies (9). Since the unravelling of the mechanisms behind tumour development, it became clear that DNA is the main driving force in tumourogenesis (10) and the main intracellular target in cancer chemotherapy (11). DNA is a fountain of genetic information with a wellknown and studied structure, which makes it a frequent target in drug design. Alterations to gene expression by means of small DNA binding molecules were proposed some time ago and are constantly being improved. Targeting DNA/RNA with small molecules can give rise to versatile therapeutic results $(12,13)$. The complex created between DNA and a small molecule can modify normal gene expression leading to alterations in the regulation of cell growth (14). The mode of action for most DNA-affecting antineoplastic agents is either the inhibition of DNA synthesis or irreversible and/or reversible DNA damage. DNAsmall molecule interactions are driven by two main modes of binding: covalent and non-covalent. The two main models for the most non-covalent DNA-small molecule interaction are intercalation and groove binding (14). This review focuses on compounds belonging to these two groups. DNA minor groove binders (MGBs), one of the most widely studied type of small molecules (4), can be grouped into two functional groups: 1) substances that cause permanent DNA damage and 2) substances that react with DNA solely physically and induce reimbursement inhibition of DNA-dependent function (15). DNA intercalation provokes structural changes in DNA leading to intrusion in the recognition and function of DNAassociated proteins such as polymerases, transcription factors, DNA repair systems, and, especially, topoisomerases (16).

There are numerous articles on chemotherapeutic drugs used in clinical practice. The main goal of this review is to offer a short retrospective of DNA binding/ intercalating drugs applied in chemotherapy (Figure 1) according to their mechanism of action and origin. The drugs described in this article are the basis for future generations of anticancer therapeutics focusing on "targeted" small molecule- and protein/antibodybased drugs that will introduce receptor-targeted therapies, downstream effectors, and antiangiogenic compounds (17). Many are already in clinical use and some are promising therapeutics currently under research.

\section{DNA intercalators}

DNA intercalators are a group of compounds with diverse structure and the ability to bind firmly but reversibly to DNA by intercalation of a flat, aromatic chromophore between the base pairs (18). The only recognised forces that maintain the stability of the complex, even more than DNA alone, are van der Waals, hydrogen bonding, hydrophobic effects, and/or charge transfer forces (19). Classical intercalators have a straight, heteroaromatic ring which comes in between two neighbouring base pairs. Interaction leads to structural changes of the DNA molecule resulting in the partial unwinding of the DNA molecule and extension of DNA chain by one base pair. Most clinically-used DNA-intercalating compounds are powerful inhibitors of DNA and RNA synthesis and this has been regarded as their primary mode of action.

Their second major biological effect is the provocation of DNA damage, e.g. sister chromatid exchange (20) and micronuclei (21), which is closely correlated with cytotoxicity levels (18). Moreover, DNA damage can originate from the interference of DNA-intercalating agents with topoisomerase II (topo II), an enzymatic protein entrusted with the role of maintaining the correct topological properties of DNA in cells (18). In general, topoisomerase are nuclear enzymes necessary for the maintenance of DNA structure. They are direct participants in the recognition of DNA and the fundamental steps of cellular growth when DNA replication is active, as well as in the $S$ phase of the cell cycle in which topology of DNA plays a significant role. Topoisomerases influence chromatin arrangement in the $\mathrm{M}$ phase of the cell cycle indicating that they can be poisoned not only in the $\mathrm{S}$ but also in the M phase (19). Topoisomerases can be grouped into two main classes: topoisomerase I (topo I), which breaks only one strand of DNA and topo II, which breaks both strands of the duplex (19). Alterations in DNA topo II have been identified in tumour cell lines selected for resistance to natural products, including etoposide and doxorubicin (18). Actinomycin D, bleomycin, daunorubicin, doxorubicin, elsamicin A, epirubicin, ethidium, m-AMSA, mitoxantrone are just some of the DNA intercalating drugs commonly used today as chemotherapeutics (22-28). 
Indolocarbazoles represent a family of natural products with the potential to be used in cancer treatment (29). The natural antibiotic rebeccamycin (Figure 2)isolated from Saccharothrix aerocoloniegenes (30) is representative of the indolcarbazole group and is a DNA-binding agent and inhibitor of topo I (3133).

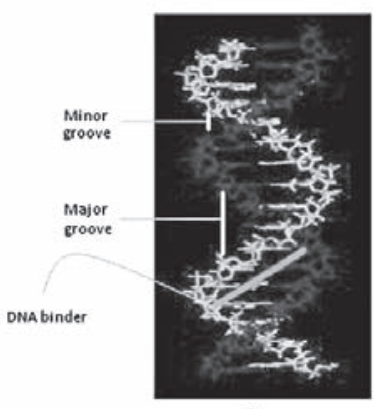

A

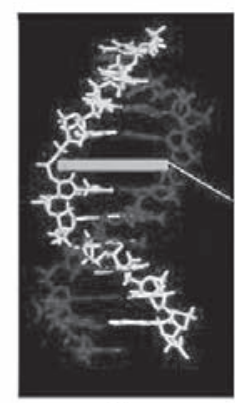

Figure 1 Schematics showing two distinct models of drug-DNA interaction

A) DNA major and minor groove binding - an isohelical drug molecule binds in the minor groove of DNA without inducing significant DNA structural changes; the complex is stabilised mainly with hydrophobic interactions;

B) Intercalation - a planar aromatic chromophore is inserted between two adjacent base pairs in the DNA helix; the complex is stabilised by hydrophobic interactions and van der Waals forces.

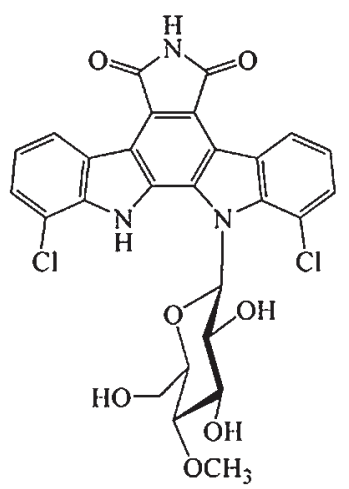

Figure 2 Chemical structure of rebeccamycin

MLN944 (XR5944) (Figure 3) is a novel bisphenazine originating from a drug development programme aimed at developing new compounds as drugs for the treatment of solid tumours (34). This agent expressed strong cytotoxic activity in a variety of in vitro and in vivo tumour models. It was designed to target both topo-I and topo-II, but experiments conducted by Sappal et al. (35) showed that the toxicity of MLN944 was not correlated with the inhibition of topo I and topo II and that treatment induced non-reversible cell cycle arrest in both the G1 and the G2-M phase.<smiles>Cc1cccc2nc3cccc(C(=O)NCCNCCNCCNC(=O)c4cccc5nc6cccc(C)c6nc45)c3nc12</smiles>

Figure 3 Chemical structure of MLN944

Two newly-synthesised drugs, named TAS-103 and DACA (Figure 4), act as dual topo poisons. TAS103 is a quinoline derivate expressing remarkable activity against subcutaneously-implanted murine and human tumours in vivo, as well as various lungmetastatic murine tumours (36). Recent studies on TAS-103 in conjunction with various approved antitumour drugs like cisplatin, if applied simultaneously, expressed a synergistic effect, which may prove beneficial for the treatment of small-cell lung cancer. TAS-103 is therefore a promising anticancer compound and is currently undergoing clinical trials (37). The antitumour activity of DACA was extremely high in certain in vivo tumour models (38). For example, DACA was efficient against transplantable Lewis lung adenocarcinoma growing as lung tumour nodules in mice and was more successful than standard drugs in various xenografted cancers (37). DACA is currently in phase I/II clinical trial as an anticancer agent. One of the most interesting facts about DACA is its unusual mode of binding to DNA. It was revealed that the intercalation of the acridine ring was accompanied by a major groove

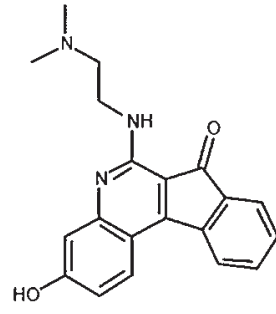

TAS-103<smiles>CN(C)CCNC(=O)c1cccc2cc3ccccc3nc12</smiles>

DACA
Figure 4 Synthetic intercalating antineoplastic compounds [adapted from (36)] 
binding of the carboxamide side chain (39). Major groove binding is usually noted with proteins and peptides and infrequently seen in small molecules (37).

Prodiginines (Figure 5) are transformed primary bacteria products with immunosuppressive and anticancer attributes, characterised by a pyrrole dipyrromethane backbone. They act as a dual topo I/II inhibitor. Their antimalignant activity has been shown in several cancer-derived cell lines (breast, lung, stomach, liver, spleen, colon, blood, and chronic myeloid leukaemia) and in mice in vivo with a xenografted liver cancer (40). Furthermore, prodiginines show negligible activity in normal cells (31). Prodigiosin, a red pigment produced by numerous strains of the bacterium Serratia marcescens, is a prodiginine scanned against dozens of cancer cell lines demonstrating an average inhibitory concentration of $2.1 \mu \mathrm{mol} \mathrm{L}^{-1}$ (41). Obatoclax (GX15-070) is a synthetic derivative of natural prodiginines and the leading candidate for clinical application. Currently, Obatoclax is in multiple phase I and phase II clinical trials for several types of cancer, used both as a single agent and in combined therapies $(42,43)$.
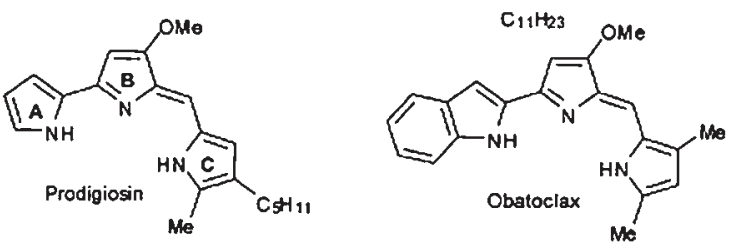

Figure 5 Prodigiosin and his derivative Obatoclax [adapted from (43)]

Anthracyclines act as topo II inhibitors. Doxorubicin and daunomycin are representatives of this group, as is aclacinomycin $\mathrm{A}$, a dual topo inhibitor with the ability to kill cells in the exponential and plateau phase by a non-selective mechanism (37). Doxorubicin (Figure 6) is an anthracycline antibiotic with antineoplastic activity. It acts as a topo II poison and is used for treating breast and ovarian cancer, lung cancer, gastric (stomach) cancer, testicular cancer, bladder and thyroide cancer, Hodgkin's and nonHodgkin's lymphoma, soft tissue sarcoma, acute leukaemia, Wilm's tumour and neuroblastoma (44). Since 2007, doxorubicin and bortezomib have been used in combined therapy for treating multiple myeloma (45). Epirubicin is also an anthracycline antibiotic. It expresses reduced myelosuppression and cardiotoxicity and has produced high response rates in early breast cancer compared to doxorubicin (46). Mitoxantrone is an anthraquinone derivate structurally and functionally very similar to doxorubicin: it acts as an intercalator and topo II poison. It is used in the treatment of prostate cancer, acute myelogenous leukaemia (AML), breast cancer, and Non-Hodgkin's lymphoma (47).

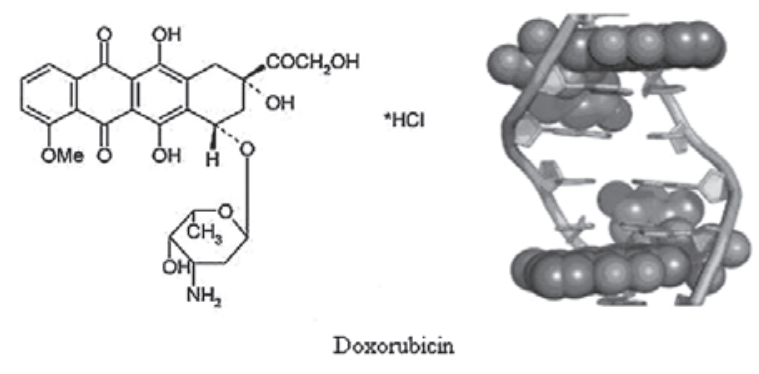

Figure 6 Doxorubicin chemical structure and 3D intercalating model [adapted from (44)]

\section{DNA groove binders}

Minor groove DNA binding compounds are a new family of antineoplastic drugs with representatives already in the process of clinical testing. The structure of these molecules is characterised by several connected aromatic rings that allow freedom of movement and torsion. Binders usually have a characteristic curved shape compatible with the DNA minor groove. The formed complex is stabilised with hydrophobic interactions (Figure 1A). Furthermore, DNA binders do not cause significant structural changes in the DNA molecule and no change to the DNA free energy structure (22). One of the most prominent characteristics of DNA minor groove binding compounds is their preferable binding to AT rich regions due to good hydrophobic interaction between the aromatic ring of the compound and second $\mathrm{C}$ atom of adenine. On cell level, DNA minor groove binders stop the cell cycle in its G2-M phase (48).

MGBs are especially interesting because of their possible effect on gene expression, pronounced affinity, and selective binding. In the last decade, many synthetic and natural analogues like distamycin A, netropsin (49), CC-1065 (50), and Hoechst 33258 (51) were tested for their antineoplastic impact. Some possessed fluorescent attributes, with antibacterial, antifungal, and antiviral properties. They can be used in combination with other drugs for cytotoxic enhancement with an aim to reduce the applied drug 
concentrations. For example, distamycin A in combination with duocarmycin A enhanced the cytotoxicity of duocarmycin A by 10 times in comparison with duocarmycin A alone (52).

Bisamidines are a group of compounds used as a base for the synthesis of new compounds with minor alterations in structure. The biological effects of bisamidines presumably originate from their inhibitory effects on transcription and replication (53). Hoechst 33258 and 33342 are representatives of the bisbenzimidazole group and probably one of the most studied DNA binding compounds (Figure 7).
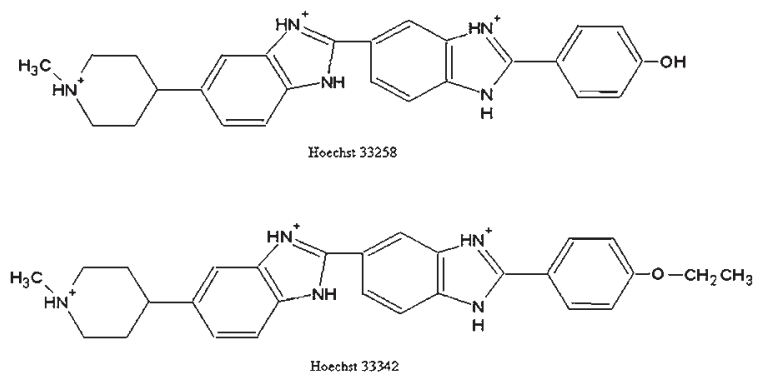

Figure 7 Chemical structure of DNA binding dyes Hoechst 33258 and 33342 used in fluorescent microscopy for DNA visualisation and detection

Hoechst 33258, known as pibenzimol, is a fluorescent reagent with a head-to-tail bisbenzimidazole structure that initially showed activity against L1210 murine leukaemia (54). In human phase I clinical trials, it exhibited mild suppressive reaction in pancreatic cancer. However, phase II did not show any objective responses (54). Since Hoechst 33258 possesses strong DNA binding power, many chemists have used it as a backbone for new compounds with different radicals and substituted groups or atoms. Not long ago, Liu et al. (55) have pinpointed Hoechst 33342 and 33258 as delegates of a class of human topo I poisons that display cytotoxic behaviour in numerous cancer cell lines. These drugs bind to the minor groove of AT-tract duplex DNA. Nevertheless, this binding mode by itself does not seem adequate to reveal biological activity as a topo I poison, because other AT-specific, minor groove-directed ligands, such as netropsin, 4',6-diamidino-2-phenylindole (DAPI), berenil, and distamycin A were proven to be powerless or inert poisons of human topo I (56). Therefore, minor groove binding by itself, even though probably required, is not sufficient to poison topo I (56). However, Hoechst 33258 has uncommon DNA binding properties. Besides settling into the minor groove of AT sequences (57), the drug can intercalate into GC-rich sequences (58). Analogue DNA sequence-dependent binding modes have been exhibited with DAPI and berenil and diphenylfuran derivatives. Hence, inactivation of topoisomerase I by Hoechst 33258 may, to a certain extent, rely on the intercalative binding mode rather than the DNA minor groove complex formation (37). Hoechst 33342 is more lipophilic than 33258 and is commonly applied for histochemical staining and flow cytometric analysis of DNA content in viable cells $(59,60)$. Curiously, Hoechst 33342 generated protein-DNA cross links and DNA strand breaks in cultured mammalian cells. G2-phase arrest and chromosome end reduplication were also pronounced effects of Hoechst 33342 treatment (61).

Terbenzimidazoles are a group of synthetic ligands that poison the human topo I enzyme and contribute to cancer cell death (49). One of its representatives is the 5-phenylterbenzimidazole derivative (5PTB), which poisons human topo I and is lethal to tumour cells that overexpress the multi-drug resistance protein (MDR) (49).

Pyrrolobenzodiazepines (PBDs) are a group of naturally occurring alkylating antitumour antibiotics. They are a class of sequence-selective DNA binding agents obtained from the thermophilic actinomycete Streptomyces refaineus (62), which includes DC-81, tomaymycin, and anthramycin (63). Anthramycin was isolated in 1963 and in spite of good antineoplastic activity against different types of tumours (Ehrlich solid carcinoma, sarcoma 180, epidermal carcinoma no.3 and leukaemia L1210 cells), the clinical application of anthramycin is limited because of its high cardio toxicity and possible appearance of acute necrosis at the site of drug application (62). SJG-136 is a new member of the PBD group. This compound exhibited significant in vivo potential for leukaemia treatment. The first phase of clinical evaluation finished in 2010 (64). The tripyrrole peptide distamycin $\mathrm{A}$ is a naturally occurring antibiotic agent obtained from the cultures of Streptomyces distallicus (62). It binds exclusively to the minor groove of DNA with high selectivity for the AT rich region (65). Distamycin $\mathrm{A}$ (Figure 8 ) is a potent inhibitor of Werner and Bloom syndrome helicases and a dual inhibitor of topo I and II. It inhibits RNA polymerase II transcription by blocking chain elongation as well as intensifying transcription at natural RNA polymerase II pause sites (66). One significant representative among distamycin 


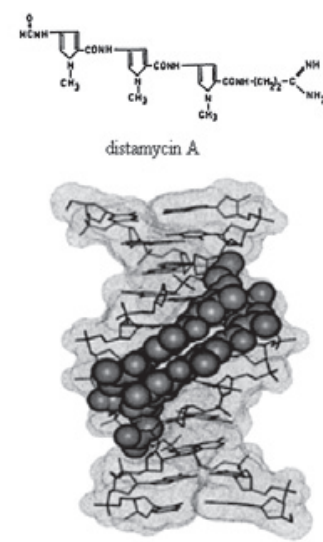

Figure 8 Distamycin A chemical structure and $3 D$ overview of binding in side of a DNA molecule

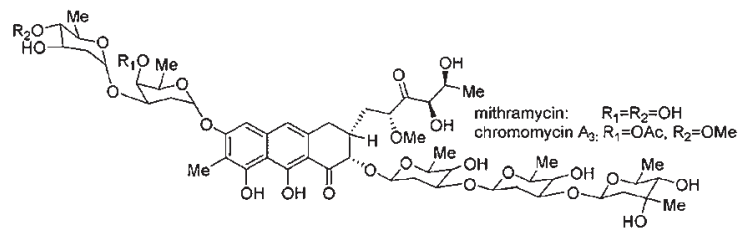

Figure 9 Aureolic acid group of antineoplastic compounds [adapted from (66)]

A derivatives is tallimustine (TAM) (67). Until recently, TAM was the only clinically developed derivative (68). TAM passed phase I of clinical trials but was halted in phase II $(69,70)$, because it showed severe myelotoxicity (68). Netropsin (71) acts in the same way as distamycin A, inhibiting Werner and Bloom syndrome helicases and dually inhibiting topo I/II.

Other relatively frequently used drugs include the natural antibiotic duocarmycin SA, member of the CC-1065 family (72), which is a tremendously powerful cytostatic compound against different cancer cell lines and hence one of the most powerful anticancer agents known so far (73). Mithramycin (MTR) and chromomycine (Figure 9) have a similar mode of binding to GC-rich DNA sequences in the minor groove and belong to the aureolic acid group of anticancer drugs (66).

\section{CONCLUSION}

The substances listed in this article are just some of the most frequent chemotherapeutic drugs and their forerunners. The mechanism of their action is specific, but they have no particular selectivity toward malignant cells. The medicine of tomorrow will need to implement a personalised approach with tailored therapy for specific patient transcription/genotype profiles. Acquisition of effective substances through gene profiling in combination with proficiency gained through applied antimalignant therapy is the future recipe for successful treatment.

\section{REFERENCES}

1. Turner PR, Denny WA. The mutagenic properties of DNA minor-groove binding ligands. Mutat Res 1996;355:141-69. PMID: 8781582

2. Ganapathy V, Thangaraju M, Prasad PD. Nutrient transporters in cancer: relevance to Warburg hypothesis and beyond. Pharmacol Therap 2009;121:29-40. doi: 10.1016/j. pharmthera.2008.09.005

3. Newman DJ, Cragg GM. Natural products as sources of new drugs over the last 25 years. J Nat Prod 2007;70:461-77. doi: $10.1021 / \mathrm{np} 068054 \mathrm{v}$

4. Hamilton PL, Arya DP. Natural product DNA major groove binders. Nat Prod Rep 2012;29:134-43. doi: 10.1039/ c1np00054c

5. Dervan PB. Molecular recognition of DNA by small molecules. Bioorg Med Chem 2001;9:2215-35. doi: 10.1016/ S0968-0896(01)00262-0

6. Wasselbourg S, Lauber K. Mechanisms of anticancer drug action. In: Los M, Gibson SB, editors. Apoptotic pathways as targets for novel therapies in cancer and other diseases. New York (NY): Springer Science Business Media, Inc.; 2005. p. 31-55.

7. Höti N, Ma J, Tabassum S, Wang Y, Wu M. Triphenyl tin benzimidazolethiol, a novel antitumor agent, induces mitochondrial-mediated apoptosis in human cervical cancer cells via suppression of HPV-18 Encoded E6. J Biochem 2003;134:521-8. PMID: 14607978

8. Liu J, Campen A, Huang S, Peng S, Ye X, Palakal M, Dunker $\mathrm{KA}, \mathrm{Xia}$ Y, Li S. Identification of a gene signature in cell cycle pathway for breast cancer prognosis using gene expression profiling data. BMC Med Genomics 2008;1:3951. doi: 10.1186/1755-8794-1-39

9. Haq I. Thermodynamics of drug-DNA interactions. Arch Biochem Biophys 2002;15:1-15. PMID: 12061796

10. Gurova K. New hopes for old drugs: revising DNA-binding small molecules as anticancer agents. Future Oncol 2009;5:1685-704. doi: 10.2217/fon.09.127

11. Leal JFM, Martínez-Díez M, García-Hernández V, Moneo V, Domingo A, Bueren-Calabuig JA, Negri A, Gago F, Guillén-Navarro MJ, Avilés $\mathrm{P}$, Cuevas C, García-Fernández LF, Galmarini CM. PMO1183, a new DNA minor groove covalent binder with potent in vitro and in vivo anti-tumour activity. Br J Pharmacol 2010;161:1099-110. doi: 10.1111/ j.1476-5381.2010.00945.x

12. Tidwell RR, Boykin DW. Dicationic DNA minor groove binders as antimicrobial agents. In: Demeunynck M, Bailly C, Wilson WD, editors. DNA and RNA binders: from small molecules to drugs. Vol. 2. Weinheim: Wiley-VCH; 2003. p. 414-60. 
13. Xi H, Davis E, Ranjan N, Xue L, Hyde-Volpe D, Arya DP. Thermodynamics of nucleic acid "shape readout" by an aminosugar. Biochemistry 2011;50:9088-113. doi: 10.1021/ bi201077h

14. Kumar S, Xue L, Arya DP. Neomycin-neomycin dimer: an all-carbohydrate scaffold with high affinity for AT-rich DNA duplexes. J Am Chem Soc 2011;133:7361-75. doi: 10.1021/ ja108118v

15. Zhang X, Zhang SC, Sun D, Hu J, Wali A, Pass H, FernandezMadrid F, Harbut MR, Tang N. New insight into the molecular mechanism of the biological effect of DNA minor groove binders. PLoS One. 2011;6:e25822. doi: 10.1371/ journal.pone. 0025822

16. Avendaño C, Menéndez CJ. DNA Intercalators and topoisomerase inhibitors. In: Avendano C, Menendez JC, editors. Medicinal chemistry of anticancer drugs. Oxford: Elesevier BV; 2008. p. 199-228.

17. Milano A, Perri F, Ciarmiello A, Caponigro F. Targetedtherapy and imaging response: a new paradigm for clinical evaluation? Rev Recent Clin Trials 2011;6:259-65. PMID 21682675

18. Marverti G, Cusumano M, Ligabue A, Di Pietro ML, Vainiglia PA, Ferrari A, Bergomi M, Moruzzi MS, Frassinet C. Studies on the anti-proliferative effects of novel DNAintercalating bipyridyl-thiourea-Pt(II) complexes against cisplatin-sensitive and -resistant human ovarian cancer cells. J Inorg Biochem 2008;102:699-712. PMID: 18082268

19. Martínez R, Chacón-García L. The Search of DNAintercalators as antitumoral drugs: what it worked and what did not work. Curr Med Chem 2005;12:127-51. PMID 15638732

20. Raj AS, Heddle JA. Simultaneous detection of chromosomal aberrations and sister-chromatid exchanges: experience with DNA intercalating agents. Mutat Res 1980;78:253-60. PMID: 7432360

21. Wilson WR, Harris NM, Ferguson LR. Comparison of the mutagenic and clastogenic activity of amsacrine and other DNA-intercalating drugs in cultured V79 Chinese hamster cells. Cancer Res 1984;44:4420-31. PMID: 6547875

22. Palchaudhuri R, Hergenrother PJ. DNA as a target for anticancer compounds: methods to determine the mode of binding and the mechanism of action. Curr Opin Biotechnol 2007:18:497-503. doi: 10.1016/j.copbio.2007.09.006

23. Terakawa T, Miyake H, Muramaki M, Takenaka A, Fujisawa M. Salvage chemotherapy with methotrexate, etoposide and actinomycin D in men with metastatic nonseminomatous germ cell tumors with a choriocarcinoma component: a preliminary report. Int J Urol 2010;17:881-5. doi: 10.1111/ j.1442-2042.2010.02618.x

24. Milano A, Apice G, Ferrari E, Fazioli F, de Rosa V, de Luna AS, Laffaioli RV, Caponigro F. New emerging drugs in soft tissue sarcoma. Crit Rev Oncol Hematol 2006;59:74-84. PMID: 16533604

25. Schaich M, Illmer T, Aulitzky W, Bodenstein H, Clemens M, Neubauer A, Repp R, Schäkel U, Soucek S, Wandt H, Ehninger G. Intensified double induction therapy with high dose mitoxantrone, etoposide, m-amsacrine and high dose ara-C for elderly acute myeloid leukemia patients aged 61-65 years. Haematologica 2002;87:808-15. PMID: 12161356

26. Fiocchi SC, Selting KA, Rosenberg MP, Kolli P, Lenaz G, Henry C. An open-label, dose-escalating phase I study of elsamitrucin (SPI 28090) in treatment of malignant solid tumors in dogs. J Vet Intern Med 2011;25:897-902. doi: 10.1111/j.1939-1676.2011.0752.x

27. He Y, Zhang L, Song C. Luteinizing hormone-releasing hormone receptor-mediated delivery of mitoxantrone using LHRH analogs modified with PEGylated liposomes. Int J Nanomedicine 2010;5:697-705. PMID: 20957221

28. Mocellin S, Rossi CR, Brandes A, Nitti D. Adult soft tissue sarcomas: Conventional therapies and molecularly targeted approaches. Cancer Treat Rev 2006;32:9-27. PMID: 16338075

29. Salas JA, Méndez C. Indolocarbazole antitumour compounds by combinatorial biosynthesis. Curr Opin Chem Biol 2009;13:152-60. doi: 10.1016/j.cbpa.2009.02.003

30. Facompre M, Baldeyrou B, Bailly C, Anizon F, Marminon C, Prudhomme M, Colson P, Houssier C. DNA targeting of two new antitumour rebeccamycin derivatives. Eur J Med Chem 2002;37:925-32. PMID: 12660017

31. Bailly C, Qu X, Anizon F, Prudhomme M, Ois Riou J, Chaires JB. Enhanced binding to DNA and topoisomerase I inhibition by an analog of the antitumor antibiotic rebeccamycin containing an amino sugar residue. Mol Pharmacol 1999;55:377-85. PMID: 9927631

32. Sánchez C, Salas AP, Braña AF, Palomino M, Pineda-Lucena A, Carbajo RJ, Méndez C, Moris F, Salas JA. Generation of potent and selective kinase inhibitors by combinatorial biosynthesis of glycosylated Indolocarbazoles. Chem Commun 2009;27:4118-20. doi: 10.1039/b905068j

33. Sánchez C, Zhu L, Braña AF, Salas AP, Rohr J, Méndez C, Salas JA. Combinatorial biosynthesis of antitumor indolocarbazole compounds. PNAS 2005;102:461-6. doi: 10.1073/pnas.0407809102

34. Gamage SA, Spicer JA, Finlay GJ, Stewart AJ, Charlton P, Baguley BC, Denny WA. Dicationic bis(9-methylphenazine1-carboxamides): relationships between biological activity and linker chain structure for a series of potent topoisomerase targeted anticancer drugs. J Med Chem 2001;44:1407-15. PMID: 11311063

35. Sappal DS, McClendon KA, Fleming JA, Thoroddsen V, Connolly K, Reimer C, Blackman RK, Bulawa CE, Osheroff N, Charlton P, Rudolph-Owen LA. Biological characterization of MLN944: A potent DNA binding agent. Mol Cancer Ther 2003;3:47-58. PMID: 14749475

36. Fujimoto S. Promising antitumor activity of a novel quinoline derivative, TAS-103, against fresh clinical specimens of eight types of tumors measured by flow cytometric DNA analysis. Biol Pharm Bull 2007;30:1923-9. PMID: 17917263

37. Bailly C. Topoisomerase I poisons and suppressors as anticancer drugs. Curr Med Chem 2000;7:39-58. PMID: 10637356

38. Baguley BC, Kerr DJ. Anticancer Drug Development. San Diego (CA): Academic Press; 2001.

39. Varvaresou A, Iakovou K. Molecular modeling study of intercalation complexes of tricyclic carboxamides with d(CCGGCGCCGG)2 and d(CGCGAATTCGCG)2. J Mol Model 2010;17:2041-50. doi: 10.1007/s00894-010-0891-5

40. Williamson NR, Chawrai S, Leeper FJ, Salmond GPC. Prodiginines and their potential utility as proapoptotic anticancer agents. In: Fialho A, Chakrabarty A, editors. Emerging cancer therapy: microbial approaches and biotechnological tools. Hoboken (NJ): John Wiley \& Sons; 2010. p. 333-66. 
41. Manderville RA. Synthesis, proton-affinity and anti-cancer properties of the prodigiosin-group natural products. Curr Med Chem Anticancer Agents 2001;1:195-218. PMID: 12678767

42. Bernardes N, Seruca R, Chakrabarty AM, Fialho AM. Microbial-based therapy of cancer. Bioeng Bugs 2010;1:17890. doi: 10.4161/bbug.1.3.10903

43. Chawrai SR, Williamson NR, Salmond GPC, Leeper FJ. Chemoenzymatic synthesis of prodigiosin analoguesexploring the substrate specificity of PigC. Chem Commun 2008;16:1862-4. doi: 10.1039/B719353J

44. Cancerquest. Doxorubicin [displayed 9 June 2013]. Available at http://www.cancerquest.org/drugs/doxorubicin

45. Jakubowiak AJ, Kendall T, Al-Zoubi A, Khaled Y, Mineishi S, Ahmed A, Campagnaro E, Brozo C, Braun T, Talpaz M, Kaminski MS. Phase II trial of combination therapy with bortezomib, pegylated liposomal doxorubicin, and dexamethasone in patients with newly diagnosed myeloma. J Clin Oncol 2009;27:5015-22. doi: 10.1200/ JCO.2008.19.5370

46. Plosker GL, Faulds D. Epirubicin. A review of its pharmacodynamic and pharmacokinetic properties, and therapeutic use in cancer chemotherapy. Drugs 1993;45:788856. PMID: 7686469

47. The Scott Hamilton CARES Initiative. Mitoxantrone [displayed 9 June 2013]. Available at http://www.chemocare. $\mathrm{com} / \mathrm{bio} / \mathrm{mitoxantrone.asp}$

48. Yamori T, Matsunaga A, Sato S, Yamazaki K, Komi A, Ishizu K, Mita I, Edatsugi H, Matsuba Y, Takezawa K, Nakanishi O, Hiroshi Kohno H, Nakajima Y, Komatsu H, Andoh T, Tsuruo T. Potent antitumor activity of MS-247, a novel DNA minor groove binder, evaluated by an in vitro and in vivo human cancer cell line panel. Cancer Res 1999;59:4042-9. PMID: 10463605

49. David-Cordonnier MH, Hildebrand MP, Baldeyrou B, Lansiaux A, Keuser C, Benzschawel K, Lemster T, Pindur U. Design, synthesis and biological evaluation of new oligopyrrole carboxamides linked with tricyclic DNAintercalators as potential DNA ligands or topoisomerase inhibitors. Eur J Med Chem 2007;42:752-71. PMID: 17433851

50. Bhuyan BK, Newell KA, Crampton SL, Von Hoff DD. CC1065 (NSC 298223), a most potent antitumor agent: kinetics of inhibition of growth, DMA synthesis, and cell survival. Cancer Res 1982;42:3532-7. PMID: 7105029

51. Wanga X, Chub N, Wanga N, Chao Liua Q, Jianga C, Wanga $\mathrm{X}$, Ikejima T, Chenga M. Newly synthesized bis-benzimidazole derivatives exerting anti-tumor activity through induction of apoptosis and autophagy. Bioorg Med Chem Lett 2012;22:6297-300. doi: 10.1016/j.bmcl.2012.06.102

52. Hirota M, Fujiwara T, Mineshita S, Sugiyama H, Teraoka H. Distamycin A enhances the cytotoxicity of duocarmycin A and suppresses duocarmycin A-induced apoptosis in human lung carcinoma cells. Int J Biochem Cell Biol 2007;39:98896. doi: 10.1016/j.biocel.2007.01.019

53. Bielawski K, Wolczyñski S, Bielawska A. DNA-binding properties and cytotoxicity of extended aromatic bisamidines in breast cancer MCF-7 cells. Pol J Pharmacol 2001;53:1437. PMID: 11787954

54. Yang YH, Cheng MS, Wang QH, Nie H, Liao N, Wang J, Chen H. Design, synthesis, and anti-tumor evaluation of novel symmetrical bis-benzimidazoles. Eur J Med Chem 2009;44:1808-12. doi: 10.1016/j.ejmech.2008.07.021

55. Chen AY, Yu C, Bodley A, Peng LF, Liu LF. A new mammalian DNA topoisomerase I poison Hoechst 33342: cytotoxicity and drug resistance in human cell cultures. Cancer Res 1993;53:1332-7. PMID: 8383008

56. Pilch DS, Xu Z, Sun Q, Lavoie EJ, Liu LF, Breslauer KJ. A terbenzimidazole that preferentially binds and conformationally alters structurally distinct DNA duplex domains: A potential mechanism for topoisomerase I poisoning. Proc Natl Acad Sci USA 1997;94:13565-70.

57. Bailly C, Chessaro G, Carrasco C, Joubert A, Mann J, Wilson WD, Neidle S. Sequence-specific minor groove binding by bis-benzimidazoles: water molecules in ligand recognition. Nucleic Acids Res 2003;31:1514-24. PMID: 12595560

58. Vekshin N. Binding of Hoechst with nucleic acids using fluorescence spectroscopy. J Biophys Chem 2011;2:443-7. doi: $10.4236 / j b p c .2011 .24052$

59. Invitrogen. Hoechst Stains [displayed 9 June 2013]. Available at http://probes.invitrogen.com/media/pis/mp21486.pdf

60. Leitner F, Paillasson S, Ronot X, Demongeot J. Dynamic functional and structural analysis of living cells: new tools for vital staining of nuclear DNA and for characterisation of cell motion. Acta Biotheor 1995;43:299-317. PMID: 8919346

61. Chen AY, Yu C, Gatto B, Liu LF. DNA minor groove-binding ligands: A different class of mammalian DNA topoisomerase I inhibitors. Proc Natl Acad Sci USA 1993;90:8131-5. doi: 10.1073/pnas.90.17.8131

62. Baraldi PG, Cacciari B, Guiotto A, Romagnoli R, Zaid AN, Spalluto G. DNA minor-groove binders: results and design of new antitumor agents. Il Farmaco 1999;54:15-25. doi: 10.1016/S0014-827X(98)00102-5

63. Kamal A, Reddy PS, Reddy DR, Laxman E. DNA binding potential and cytotoxicity of newly designed pyrrolobenzodiazepine dimers linked through a piperazine side-armed-alkane spacer. Bioorg Med Chem 2006;14:38594. PMID: 16185884

64. ClinicalTrails.gov. SJG-136 in Treating Patients With Relapsed or Refractory Acute Leukemia, Myelodysplastic Syndromes, Blastic Phase Chronic Myelogenous Leukemia, or Chronic Lymphocytic Leukemia [displayed 9 June 2013]. Available at http://clinicaltrials.gov/ct2/show/ NCT00301769

65. Baron RM, Lopez-Guzman S, Riascos DF, Macias AA, Layne MD, Cheng G, Harris C, Chung SW, Reeves R, von Andrian UH, Perrella MA. Distamycin A inhibits HMGA1-binding to the P-selectin promoter and attenuates lung and liver inflammation during murine endotoxemia. PLoS One 2010;5:e10656. doi: 10.1371/journal.pone.0010656

66. Nelson SM, Ferguson LR, Denny WA. Non-covalent ligand/ DNA interactions: Minor groove binding agents. Mutat Res 2007;623:24-40. PMID: 17507044

67. Cortesi R, Romagnoli R, Drechsler M, Menegatti E, Zaid AN, Ravani L, Esposito E. Liposomes- and ethosomesassociated distamycins: as comparative study. J Liposome Res 2009;20:277-85. doi: 10.3109/08982100903443057

68. Cozzi P. A new class of cytotoxic DNA minor groove binders: alpha-halogenoacrylic derivatives of pyrrolecarbamoyl oligomers. Il Farmaco 2001;56:57-65. doi: 10.1016/S0014827X(01)01009-6 
69. Vialleta TBJ, Stewart D, Shepherdd F, Ayoubb J, Cormief Y, DiPietrof N, Stewardg W. Tallimustine is inactive in patients with previously treated small cell lung cancer. A phase II trial of the National Cancer Institute of Canada Clinical Trials Group. Lung Cancer 1996;15:367-73. PMID: 8959681

79. Punt CJA, Humblet Y, Roca E, Dirix LJ, Wainstein R, Polli A, Corradino I. Tallimustine in advanced previously untreated colorectal cancer, a phase II study. Br J Cancer 1996;73:8034. PMID: 8611384

71. Neidle S, Kelland LR, Trent JO, Simpson IJ, Boykin DW, Kumar A, Wilson WD. Cytotoxicity of bis(Phenylamidiniu m)furan alkyl derivatives in human tumour cell lines: realation to DNA minor groove binding. Bioorg Med Chem Lett 1997;7:1403-8. doi: 10.1016/S0960-894X(97)00229-1

72. Smith JA, Bifulco G, Case DA, Boger DL, Gomez-Paloma L, Chazin WJ. The Structural basis for in situ activation of DNA alkylation by duocarmycin. J Mol Biol 2000;300:1195204. PMID: 10903864

73. Tietze LF, Schuster HJ, Schmuck K, Schuberth I, Alves F. Duocarmycin-based prodrugs for cancer prodrug monotherapy. Bioorg Med Chem 2008;16:6312-8. doi: 10.1016/j.bmc.2008.05.009 


\title{
Sažetak
}

\section{DNA-VEZUJUĆI ANTITUMORSKI SPOJEVI - INTERKALIRAJUĆI I MALI UTOR-VEZUJUĆI LIJEKOVI}

Novo oružje u borbi protiv zloćudnih bolesti su spojevi koji se umeću u dvolančanu strukturu deoksiribonukleinskih kiselina (DNA) ili se vezuju na mali utor DNA. Navedene skupine kemoterapeutika primarno ciljaju molekulu DNA te utječu na stanični ciklus što vodi do smrti brzo dijelećih stanica. Uglavnom su derivati organskih spojeva prirodnog podrijetla, izoliranih iz mikroorganizama ili biljaka. DNA umetnuti spojevi uglavnom djeluju kao otrovi enzima topoizomeraza I i/ili II a spojevi koji se vezuju na mali utor DNA imaju kombinirani mehanizam djelovanja pri čemu je jedan od koraka i otrovanje topoizomeraza. U ovom preglednom članku dajemo pregled nekih od spojeva koji se umeću u molekulu DNA ili vezuju na mali utor DNA, a koji se primjenjuju u kemoterapiji, njihova podrijetla i kemijske strukture.

KLJUČNE RIJEČI: derivati organskih spojeva, kemoterapija, mali utor DNA vezujući spojevi

\section{CORRESPONDING AUTHOR:}

\author{
Katarina Mišković \\ Faculty of Medicine \\ J.Huttlera 4 \\ 31000 Osijek \\ Croatia \\ E-mail:kmiskovic@mefos.hr
}

